\title{
Synthesis of a New Series of Quinolinoxymethylcoumarins as Potent Anticancer Agents
}

D Shamala*, K Shivashankar ${ }^{\dagger}$, Vijaykumar P Rasal ${ }^{\ddagger}$ and Vineela Pandi ${ }^{\S}$.

\section{Abstract}

4-Bromomethylcoumarins (1a-f) were reacted with 8hydroxyquinoline to yield quinolinoxymethylcoumarins (2a-f). The structure of all the synthesized compounds were confirmed by spectral studies and screened for their anticancer activities against Dalton's Ascitic lymphoma (DAL) and Ehrlich Ascites Carcinoma (EAC) cell lines. Out of these, compound $(\mathbf{2 b})(\mathrm{R}=6-\mathrm{OMe})$ was found to be the most potent cytotoxic compound against DAL and EAC cell lines.

Keywords: 4-Bromomethylcoumarins, Coumarins, Quinoline, Cytotoxic activity.

\section{Introduction}

A large number of naturally occurring compounds possessed heterocyclic rings as an important part of their structure. Such compounds including indole, quinoline, benzimidazole, coumarins

\footnotetext{
* PG Department of Chemistry, Central College Campus, Bangalore University, (DCCCBU) Bangalore- 560001, Karnataka, India; shamalanagendra@gmail.com

† (DCCCBU); shivashankark@gmail.com.

‡ Department of Pharmacology, KLES’s College of Pharmacy (DP,KLECP), Belgaum-590 010, Karnataka, India; rasalvp@rediffmail.com

$\S$ (DPKLECP);vineela.pharma07@gmail.com
} 
and imidazopyridines are widely used as medicines. Among them, quinoline and its derivatives exhibited remarkable activities such as antimalarial [1], antiproliferative [2], photosynthesis-inhibiting [3], proteasome inhibitors [4] and antioxidative activities [5]. They also act as antifungal [6], antibacterial [7], antiprotozoic drugs as well as exhibit antineoplastics [8] and antischistosomal activity [9].

Compounds containing coumarin rings have remarkable medicinal value due to their potential anticancer [10], antimicrobial [11] and antiulcerogenic effect [12] properties. They also act as fluorescent probes [13]. In addition, 4-heteroaryloxymethylcoumarins are reported to exhibit significant biological activities such as antibacterial [14], antifungal [15], antimicrobial [16], antidiuretic [17] and anti-inflammatory activity [18].

On the basis of these literature studies, we set out to synthesize a new series of biologically active compounds containing both of these two important pharmacophores. This study presents the synthesis, characterization and in vitro cytotoxic activities of these new quinolinoxymethylcoumarins

\subsection{Chemistry}

4-Bromomethylcoumarins [19] (1a-f) were synthesized by the Pechmann cyclisation of phenols with 4-bromoethylacetoacetate [20]. 6-Methyl-4-bromomethylcoumarin reacted with 8hydroxyquinoline in the presence of anhydrous $\mathrm{K}_{2} \mathrm{CO}_{3}$ to give 6methyl-4-(quinolin-8-yloxymethyl)-chromone-2-one [21]. We have extended the same method to other substituent of 4bromomethylcoumarins (1a-f) (Scheme 1). 


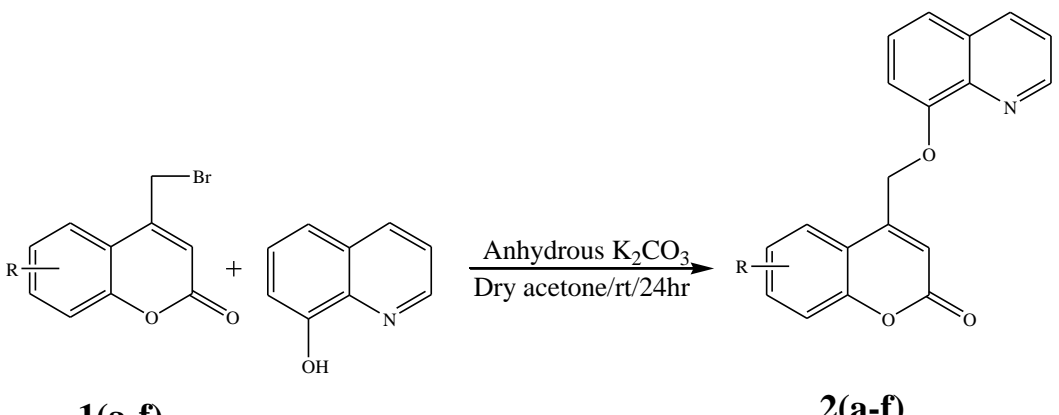

$1(\mathbf{a}-\mathbf{f})$

2(a-f)

$\mathrm{R}=\mathrm{a} ; 7-\mathrm{CH}_{3}, \mathrm{~b} ; 6-\mathrm{OMe}, \mathrm{c} ; 5,6-\mathrm{Benzo}, \mathrm{d} ; 6-\mathrm{Cl}, \mathrm{e} ; 6-\mathrm{Br}, \mathrm{f} ; 6-\mathrm{F}$.

Scheme 1.

\section{Results and Discussion}

\subsection{In vitro anticancer screening}

The newly synthesized compounds were evaluated for their in vitro cytotoxic activity against Dalton's Lymphoma Ascites (DAL) and Ehrlich Ascites Carcinoma (EAC) Cells using Dhamija method [22]. 5-Fluorouracil which is one of the most effective anticancer agents was used as the reference drug in this study.

The relationship between surviving fraction and drug concentration was plotted to obtain the survival curve of Dalton's Lymphoma Ascites (DAL) and Ehrlich Ascites Carcinoma (EAC) cells. The response parameter calculated was the $\mathrm{IC}_{50}$ value, which corresponds to the concentration required for $50 \%$ inhibition of cell viability. The $\mathrm{IC}_{50}$ of the synthesized compounds compared to the reference drug are shown in Table 1 and the results are represented graphically in Figure 1.

The investigation of in vitro cell cytotoxicity (Table 1) against DAL cell revealed that the most of the tested compounds exhibited good activity. The Compound (2b) $\left(\mathrm{R}=6-\mathrm{OCH}_{3}\right)$ was found to be the most potent against DAL cell with $\mathrm{IC}_{50}$ value of $50.76 \mu \mathrm{g} / \mathrm{mL}$. The compound (2e) $(R=6-\mathrm{Br})$ was found to be highly active against DAL cell with $\mathrm{IC}_{50}$ value of $65.87 \mu \mathrm{g} / \mathrm{mL}$. The compounds (2a) $(\mathrm{R}=$ 7- $\left.\mathrm{CH}_{3}\right),(2 \mathrm{c})(\mathrm{R}=5,6-\mathrm{Benzo})$ and $(2 \mathrm{~d})(\mathrm{R}=6-\mathrm{Cl})$ showed moderate activity against DAL cell with $\mathrm{IC}_{50}$ between 78.01 and $84.54 \mu \mathrm{g} / \mathrm{mL}$. 
The compound (2f) $(\mathrm{R}=6-\mathrm{F})$ showed poor activity against DAL cell with $\mathrm{IC}_{50} 104.25 \mu \mathrm{g} / \mathrm{mL}$.

The investigation of in vitro cell cytotoxicity (Table-1) against EAC cell revealed that the most of the tested compounds exhibited good activity. The Compound $(\mathbf{2 b})\left(\mathrm{R}=6-\mathrm{OCH}_{3}\right)$ was the most potent compound in this screening against $\mathrm{EAC}$ cell with $\mathrm{IC}_{50}$ value of $41.25 \mu \mathrm{g} / \mathrm{mL}$. The compounds (2d) $(\mathrm{R}=6-\mathrm{Cl})$ and $(\mathbf{2 f})(\mathrm{R}=6-\mathrm{F})$ were found to be highly active against EAC cell with $\mathrm{IC}_{50}$ value between 69.96 and $56.41 \mu \mathrm{g} / \mathrm{mL}$. The compounds (2a) $\left(\mathrm{R}=7-\mathrm{CH}_{3}\right)$, (2c) $(\mathrm{R}=5,6$-Benzo) and (2e) $(\mathrm{R}=6$-Br $)$ showed poor activity against EAC cell with $\mathrm{IC}_{50}$ between 104.67 and $115.23 \mu \mathrm{g} / \mathrm{mL}$.

\begin{tabular}{|c|l|c|c|}
\hline Compound & \multicolumn{1}{|c|}{$\mathbf{R}$} & DAL $\mathbf{I C}_{\mathbf{5 0}}$ & EAC $\mathbf{I C}_{\mathbf{5 0}}$ \\
\hline 2a & 7- $\mathrm{CH}_{3}$ & 84.54 & 110.34 \\
\hline 2b & 6-OCH & 50.76 & 41.25 \\
\hline 2c & $5,6-\mathrm{Benzo}$ & 78.01 & 104.67 \\
\hline 2d & 6-Cl & 81.25 & 69.96 \\
\hline 2e & 6-Br & 65.87 & 115.23 \\
\hline 2f & 6-F & 104.25 & 56.41 \\
\hline \multicolumn{2}{|c|}{ 5-Flurouracil } & 41.60 & 41.60 \\
\hline
\end{tabular}

Table 1: Result of in vitro cytotoxic activity of the synthesized compounds against DAL \& EAC cells.

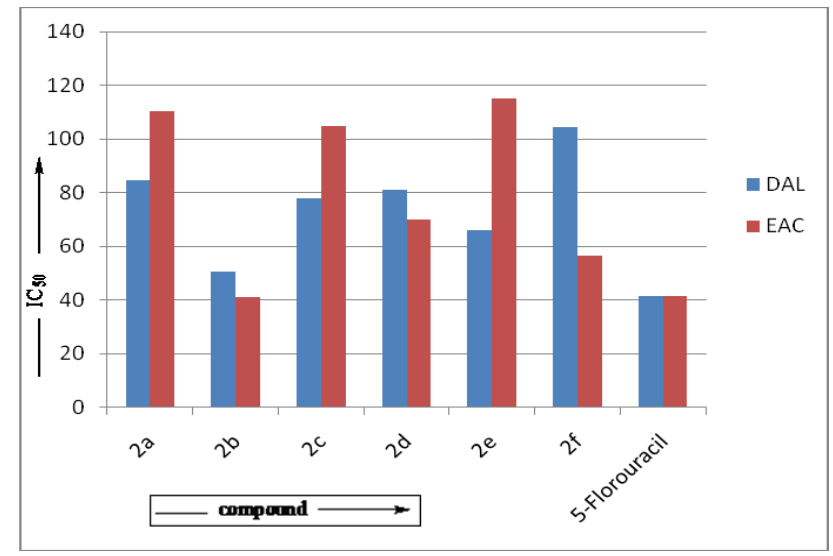

Figure 1: $\mathrm{IC}_{50} \mu \mathrm{g} / \mathrm{mL}$ of the synthesized compounds and 5-Flourouracil against DAL \& EAC cells. 


\section{Experimental section}

\subsection{General}

The melting points were determined by open capillary method using electric melting point apparatus and are uncorrected. The IR spectra ( $\mathrm{KBr}$ disc) were recorded on a Shimadzu-8400S FT-IR Spectrophotometer. ${ }^{1} \mathrm{H}$ NMR and ${ }^{13} \mathrm{C}$ NMR were recorded on Bruker $400 \mathrm{MHz}$ spectrometer by using $\mathrm{CDCl}_{3}$ as a solvent and TMS as an internal standard. The chemical shifts are expressed in $\delta$ ppm. The purity of the compound was checked by TLC.

\subsection{General procedure for the synthesis of 4-(quinolin-8- yloxymethyl)-chromone-2-one (2a-f).}

8-Hydroxyquinoline $(0.493 \mathrm{~g}, 3.4 \mathrm{mmol})$ and anhydrous $\mathrm{K}_{2} \mathrm{CO}_{3}$ $(1.38 \mathrm{~g}, 10 \mathrm{mmol})$ were stirred in $25 \mathrm{ml}$ of dry acetone for $30 \mathrm{~min}$. One of the 4-bromomethylcoumarins $\mathbf{1}(\mathbf{a}-\mathbf{f})(3.4 \mathrm{mmol})$ was added and stirring was continued for $24 \mathrm{~h}$. The reaction mixture was concentrated to one fourth volume and poured on to crushed ice. The solid separated was filtered and washed with $10 \mathrm{ml}$ of $5 \% \mathrm{HCl}$. Then, it was washed with $50 \mathrm{ml}$ of cold water. The crude product was dried and recrystallised from ethanol.

7-Methyl-4-(quinolin-8-yloxymethyl)-chromen-2-one. (2a)

Yield 95\%; colorless solid; m.p. 227 - $230^{\circ} \mathrm{C}$; IR (KBr, cm-1) $1725 \mathrm{~cm}^{-1}$ (lactone $\mathrm{C}=\mathrm{O}) ;{ }^{1} \mathrm{H}$ NMR $\left(400 \mathrm{MHz}, \mathrm{CDCl}_{3}\right)$ : $\delta 2.52\left(\mathrm{~s}, 3 \mathrm{H}, 7-\mathrm{CH}_{3}\right)$, $5.64\left(\mathrm{~s}, 2 \mathrm{H}, \mathrm{OCH}_{2}\right), 6.71\left(\mathrm{~s}, 1 \mathrm{H}, \mathrm{C}_{3}-\mathrm{H}\right), 7.0-8.99$ (m, 9H, Ar-H): ${ }^{13} \mathrm{C}$ NMR $\left(400 \mathrm{MHz}, \mathrm{CDCl}_{3}\right): \delta 21.26,67.20,110.94,114.12,117.41$, $117.61,121.79,122.43,123.79,126.91,130.17,133.47,134.65,136.69$, $140.58,149.99,150.10,152.33,153.73,161.17$.

6-Methoxy-4-(quinolin-8-yloxymethyl)-chromen-2-one. (2b)

Yield 90\%; yellow solid; m.p. $155-160{ }^{\circ} \mathrm{C}$; IR $\left(\mathrm{KBr}, \mathrm{cm}^{-1}\right) 1735 \mathrm{~cm}^{-1}$ (lactone $\mathrm{C}=\mathrm{O}) ;{ }^{1} \mathrm{H} \mathrm{NMR}\left(400 \mathrm{MHz}, \mathrm{CDCl}_{3}\right): \delta 3.81\left(\mathrm{~s}, 3 \mathrm{H}, \mathrm{OCH}_{3}\right)$, 5.67 (s, 2H, OCH $), 6.75$ (s, 1H, C $3-\mathrm{H}), 7.0-8.10$ (m, 9H, Ar-H).

1-(Quinolin-8-yloxymethyl)-benzo(f)chromen-3-one .(2c)

Yield 85\%; yellow solid; m.p. $185-188{ }^{\circ} \mathrm{C}$; IR $\left(\mathrm{KBr}, \mathrm{cm}^{-1}\right) 1720 \mathrm{~cm}^{-1}$ (lactone $\mathrm{C}=\mathrm{O}) ;{ }^{1} \mathrm{H}$ NMR $\left(400 \mathrm{MHz}, \mathrm{CDCl}_{3}\right): \delta 6.0\left(\mathrm{~s}, 2 \mathrm{H}, \mathrm{OCH}_{2}\right), 6.96$ - 9.0 (m, $\left.\mathrm{C}_{3}-\mathrm{H} \& 12 \mathrm{H}, \mathrm{Ar}-\mathrm{H}\right)$. 
6-Chloro-4-(quinolin-8-yloxymethyl)-chromen-2-one. (2d)

Yield 70\%; colorless solid; m.p. $225-227^{\circ} \mathrm{C}$; IR $\left(\mathrm{KBr}, \mathrm{cm}^{-1}\right) 1725 \mathrm{~cm}^{-1}$ (lactone $\mathrm{C}=\mathrm{O}) ;{ }^{1} \mathrm{H}$ NMR $\left(400 \mathrm{MHz}, \mathrm{CDCl}_{3}\right): \delta 5.55\left(\mathrm{~s}, 2 \mathrm{H}, \mathrm{OCH}_{2}\right)$, $6.80\left(\mathrm{~s}, 1 \mathrm{H}, \mathrm{C}_{3}-\mathrm{H}\right), 7.10$ - 9.01 (m, 9H, Ar-H).

6-Bromo-4-(quinolin-8-yloxymethyl)-chromen-2-one. (2e)

Yield 73\%; brown solid; m.p. $202-207^{\circ} \mathrm{C}$; IR $\left(\mathrm{KBr}, \mathrm{cm}^{-1}\right) 1721 \mathrm{~cm}^{-1}$ (lactone $\mathrm{C}=\mathrm{O}) ;{ }^{1} \mathrm{H}$ NMR $\left(400 \mathrm{MHz}, \mathrm{CDCl}_{3}\right): \delta 5.65\left(\mathrm{~s}, 2 \mathrm{H}, \mathrm{OCH}_{2}\right)$, $6.79\left(\mathrm{~s}, 1 \mathrm{H}, \mathrm{C}_{3}-\mathrm{H}\right), 7.10$ - $9.0(\mathrm{~m}, 9 \mathrm{H}, \mathrm{Ar}-\mathrm{H})$.

6-Fluoro-4-(quinolin-8-yloxymethyl)-chromen-2-one. (2f)

Yield 40\%; colorless solid; m.p. 229 - $232{ }^{\circ} \mathrm{C}$; IR $\left(\mathrm{KBr}, \mathrm{cm}^{-1}\right) 1722 \mathrm{~cm}^{-1}$ (lactone $\mathrm{C}=\mathrm{O}) ; \quad{ }^{1} \mathrm{H}$ NMR $\left(400 \mathrm{MHz}, \mathrm{CDCl}_{3}\right): \delta 5.57\left(\mathrm{~s}, 2 \mathrm{H}, \mathrm{OCH}_{2}\right)$, $6.80\left(\mathrm{~s}, 1 \mathrm{H}, \mathrm{C}_{3}-\mathrm{H}\right), 7.09$ - 9.0 (m, 9H, Ar-H).

\section{Conclusion}

The methoxy substitution at 6-position of coumarin moiety was found to enhance the in vitro cytotoxicity against both DAL and EAC cell lines.

\section{Acknowledgement}

We gratefully acknowledge the financial support from UGC-DRS programme. We are also thankful to Indian Institute of Science, Bangalore for the spectral analysis.

\section{References}

[1] B. N. Acharya, D. Thavaselvam and M. P. Kaushik, "Synthesis and antimalarial evalution of novel pyridine quinoline hydrids", Med. Chem. Res., 17, 487- 494, 2008. doi: 10.1007/s00044008-9092-5

[2] P. Barraja, D. Patrizia, M. Alessandra, D. Gaetano, C. Girola, G. Viola, V. Daniel and D. Francesco, "Pyrrolo[2,3-h]quinolinones: A new ring system with potent photoantiproliferative activity", Bioorg. Med. Chem., 14, 8712-8728, 2006. doi:10.1016/j.bmc.2006.07.061 
[3] M. Robert, J. Jampilek, K. Katarina, D. R. Richardson, D. Kalinowski, P. Barbara, F. Jacek, N. Halina, A. Palkaa and J. Polanskia, "Investigating biological activity spectrum for novel quinoline analogues", Bioorg. Med. Chem., 15, 1280-1288, 2007. doi:10.1016/j.bmc.2006.11.020

[4] R. L. Harshani, K. Aslamuzzaman, L. Yunting, Robert, G. Yiyu, S. Jain, K. Daniel, S. Daniel, C. G. Wayne, M. S. Said, "Synthesis and biological evaluation of naphthoquinone analogs as a novel class of proteasome inhibitors", Bioorg. Med. Chem., 18, 5576-5592, 2010. doi: 10.1016/j.bmc.2010.06.038

[5] K. V. Shashidhara, K. Abdesh, G. Bhatia, M. M. Khan, A. K. Khanna and J. K. Saxena, "Antidyslipidemic and antioxidative activities of 8-hydroxyquinoline derived novel keto-enamine schiffs bases", Eur. J. Med. Chem., 44, 1813-1818, 2009. doi:10.1016/j.ejmech.2008.08.004

[6] M. M. Patel, M. D. Mali and S. K. Patel, "Bernthsen synthesis, antimicrobial activities and cytotoxicity of acridine derivatives", Bioorg. Med. Chem. Lett., 20, 6324-6326, 2010.

[7] M. D. Braccio, G. Grossi, G. Roma, M. G. Signorello and G. Leoncini, "Synthesis and in vitro inhibitory activity on human platelet aggregation of novel properly substituted 4-(1piperazinyl)coumarins", Eur. J. Med. Chem., 39, 397-409, 2004.

[8] X. Zhou, X. B. Wang, T. Wang and L. Y. Kong, "Design, synthesis, and acetylcholinesterase inhibitory activity of novel coumarin analogues", Bioorg. Med. Chem., 16, 8011-8021, 2008. doi: 10.1016/j.b mc2008.07.068

[9] F. E. Ahmad, G. Allam, S. A. A. Abdelaziz, A. A. Hamid and I. A. Maghrabi, "Design, synthesis, anti-schistosomal activity and molecular docking of novel 8-hydroxyquinoline-5-sufonyl 1,4diazepine derivatives", Bioorg. Med. Chem., 46, 17-25, 2013. doi: 10.1016/j.bioorg.2012.10.003

[10]T. K. Joanna, H. Elzbieta, H. Kruszewska, W. Irena and D. Maciejewska, "Synthesis and pharmacological activity of $\mathrm{O}$ aminoalkyl derivatives of 7-hydroxycoumarin", Eur. J. Med. Chem., 46, 2252-2263, 2011. doi:10.1016/j.ejmech.2011.03.006

[11] M. Basanagouda, K. Shivashankar, M. V. Kulkarni, V. P. Rasal, H. Patel, S. S. Mutha and A. A. Mohite, "Synhesis and antimicrobial studies on novel sulfonamides containing 4-azidomethyl coumarin", Eur. J. Med. Chem., 45, 1151-1157, 2010.

[12]G. S. Hassan and G. A. Soliman, "Design, synthesis and antiulcerogenic effect of some of furo-salicylic acid derivatives on 
acetic acid-induced ulcerative colitis", Eur. J. Med. Chem., 45, 41044112, 2010. doi: 10.1016/j.ejmech.2010.05.071

[13] L. A. Shastri, K. Shivashankar and M. V. Kulkarni, "The synthesis of pyrrole biscoumarins, new structures for fluorescent probes", Tetrahedron Lett., 48, 7215-7217, 2007. doi:10.1016/j.tetlet.2007.07.189.

[14] K. Shivashankar, M. V. Kulkarni, L. A. Shastri, V. P. Rasal and S. V. Rajendra, "The Synthesis and biological evaluation of regioisomeric benzothiazolylcoumarins", Phosphorus, Sulfur, and Silicon, 181, 2187-2200, 2006. doi:10.1080/10426500600614550

[15] K. Shivashankar, L. A. Shastri, M. V. Kulkarni, V. P. Rasal and D. M. Saindane, "Multi-component reactions of formyl-4aryloxymethylcoumarins under microwave irradiation", J. Indian Chem. Soc., 86, 265-271, 2009.

[16] K. Shivashankar, L. A. Shastri, M. V. Kulkarni, V. P. Rasal and D. M. Saindane, "Halogenated 4-aryloxymethylcoumarins as potent antimicrobial agents", J. Indian Chem. Soc., 85, 1163-1168, 2008.

[17] N. B. Yaragatti, M. V. Kulkarni, M. D. Ghate, S. S. Hebbar and G. R. Hegde, "Synthesis and biological evaluation of some new coumarinyl thiazolopyrimidinones", J. Sulfur. Chem., 31, 123-133, 2010. doi:10.1080/17415990903569544

[18]K. Shivashankar, L. A. Shastri, M. V. Kulkarni, V. P. Rasal and S. V. Rajendra, "Synthetic and biological studies on 4aryloxymethylcoumarinylthiazolidinones", Phosphorus, Sulfur, and Silicon, 183, 56-68, 2008. doi:10.1080/10426500701555801

[19]N. B. Yaragatti and M. V. Kulkarni, "Synthesis of novel mercury heterocycles", Polyhedron. 29, 2857-2861, 2010. doi:10.1016/j.poly.2010.07.010.

[20]Burger and G.E. Ulloyt, "Analgesic studies. $\beta$-Ethyl and $\beta$ isopropyl amine derivative of pyridine and thiazole", J. Org. Chem., 12, 342-355, 1947.

[21]H. Revankar, M. V. Kulkarni and G. N. Anil kumar, "Crystal structure of 6-methyl-4-[(quinolin-8-yloxy)methyl]-2H-chromen2-one", X-ray Structure Analysis Online., 29, 5-7, 2013.

[22] I. Dhamija, Nitesh Kumar, S.N. Manjula, V. Parihar, M. Manjunath Setty and K.S.R. Pai. "Preliminary evaluation of in vitro cytotoxicity and in vivo antitumor activity of Premna herbacea Roxb. in Ehrlich ascites carcinoma model and Dalton's lymphoma ascites model", Exp. Toxicol. Pathol., 65, 235-242, 2013. doi:10.1016/j.etp.2011.08.009. 